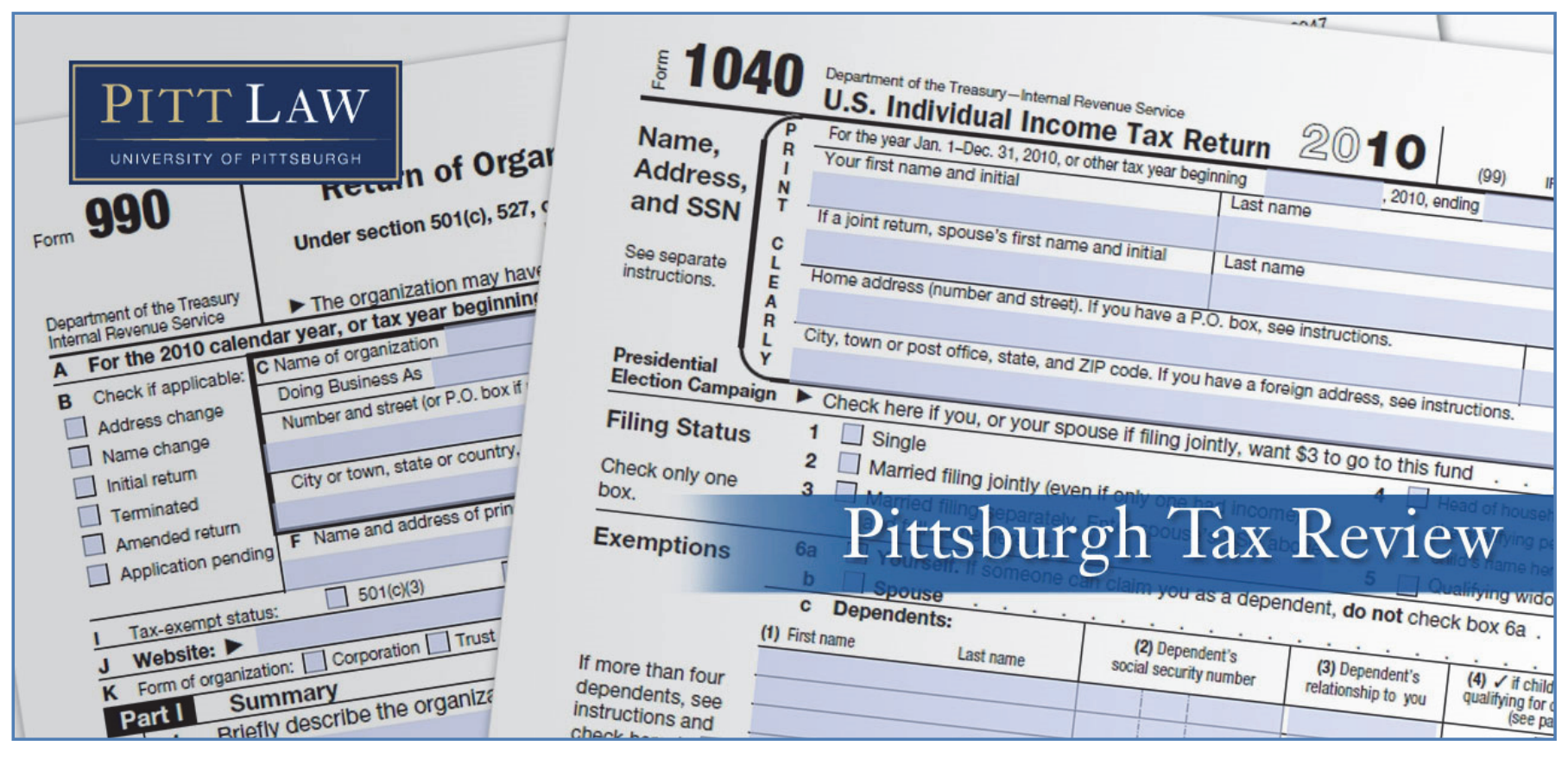

Volume 19 (2021) | ISSN 1932-1821 (print) 1932-1996 (online)

DOI 10.5195/taxreview.2021.148| http://taxreview.law.pitt.edu

\title{
COMMUNITY-BASED TAX INCENTIVES
}

Edward W. De Barbieri

\section{(cc) BY-NC-ND}

This work is licensed under a Creative Commons Attribution-Noncommercial-No Derivative Works 3.0 United States License.

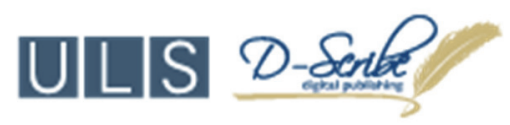

This journal is published by the University Library System of the University of Pittsburgh as part of its D-Scribe Digital Publishing Program, and is cosponsored by the University of Pittsburgh Press. 


\title{
COMMUNITY-BASED TAX INCENTIVES
}

\author{
Edward W. De Barbieri ${ }^{\dagger}$
}

\section{INTRODUCTION}

Tax incentives are chief among the levers that government officials can pull to implement place-based economic development strategies. Tax incentives are so appealing because they have incredibly attractive political features. For one, tax incentives, such as those to retain or create new jobs, afford elected officials with at least the appearance of assertive action. ${ }^{1}$ Also, tax incentives do not require increasing government collection of revenue through new taxes or fees; rather, they are future tax revenue forewent. ${ }^{2}$ As a result, tax incentives enjoy popular support because they both give the appearance of government action and do not require sacrifices in the form of increased tax rates, user fees, and the like. Those are at least some of the benefits of tax incentives, including those designed to retain jobs for constituents in particular places. $^{3}$

† Associate Professor of Law, Director, Community Economic Development Clinic, Albany Law School. Thanks to Tracy Kaye, Joe Kriesberg, Michelle D. Layser, Sandy Tarrant, Carlos Teuscher, and participants in a workshop held at the 24th Annual Critical Tax Conference for feedback and comments on the ideas in this Article, as well as earlier drafts. Thank you to Megan Bassler for excellent research assistance. Thanks also to the editors of the Pittsburgh Tax Review for including this Article in this special issue on place-based tax incentives, as well as for numerous edits and suggestions that improved the final draft of this Article.

${ }^{1}$ NAthan M. Jensen \& EdMUnd J. MAlesky, InCEnTives to PANDER: How Politicians Use CORPORATE Welfare FOR POlitiCAl Gain 1, 5-6 (2018) (discussing activities elected officials use to influence business location decisions).

${ }^{2}$ Jason Fichtner \& Jacob Feldman, When Are Tax Expenditures Really Spending? A Look at Tax Expenditures and Lessons from the Tax Reform Act of 1986, at 5 (Mercatus Ctr. at Geo. Mason, Working Paper No. 11-45, 2011) (discussing how using the tax laws to further a public policy goal is more politically palatable because tax incentives obscure the amount and size of government spending).

${ }^{3}$ Of course, there are risks, political and otherwise, of using tax incentives. In Washington State, for example, elected officials were unable to claw back any portion of tax incentives allocated to Boeing for expanding aerospace manufacturing after the company cut its workforce in the state and built a new plant and installed robot manufacturing. See S. 5952, 63d Leg., 3d Spec. Sess. (Wash. 2013). However, it is important to be clear up front about the immediate political benefits to these sorts of tax incentives. It

Pitt Tax Review | ISSN 1932-1821 (print) 1932-1996 (online)

DOI 10.5195/taxreview.2021.148 | http://taxreview.law.pitt.edu 


\section{2 | Pittsburgh Tax Review | Vol. 192021}

However, this Article is primarily concerned with a particular category of tax incentives - place-based economic development tax incentives. A central question this Article seeks to explore and answer is: who do placebased economic development tax incentives benefit? Since tax incentives offer elected officials benefits in terms of the appearance of responsiveness, one can argue that place-based incentives also offer benefits to elected officials. ${ }^{4}$ Viewed through a skeptical lens, elected officials may view themselves as benefitting from enacting "pro-growth" tax incentive polices regardless of the results. ${ }^{5}$ It is perhaps unsurprising then to discover that place-based economic development tax incentives have enjoyed bipartisan support over the previous several decades. ${ }^{6}$

Our inquiry, however, does not stop there. There are no doubt other groups who benefit from place-based economic development tax incentives and in different ways. Investors, employers, and developers benefit from such tax incentives through making new commercial real estate projects more financially attractive. ${ }^{7}$ Workers and new residents drawn to the area because of the promise of jobs and employment and attractive housing options may benefit, too, from increased economic activities and amenities. ${ }^{8}$ Existing long-time residents who may have moved to an area before it started to experience growth, development, or gentrification may benefit from increased economic activity, tax base, and growth. ${ }^{9}$ To understand who benefits and in what ways, one must have a full grasp of how place-based

is critical to weigh those political benefits against the potential detriments of place-based economic development tax incentives.

${ }^{4}$ As one strategist put it, "[G]overnors [in Washington State who] deliver Boeing jobs win reelection. Period." Reid Wilson, Boeing Machinists Agree to $777 X$ Contract on Narrow Vote, WASH. POST (Jan. 4, 2014), https://www.washingtonpost.com/blogs/govbeat/wp/2014/01/04/boeing-machinistsagree-to-777x-contract-on-narrow-vote/.

${ }^{5}$ JENSEN \& MALESKY, supra note 1 , at 16.

${ }^{6}$ Timothy P.R. Weaver, Blazing the Neoliberal Trail: Urban Political Development IN THE UNITED STATES AND THE UNITED KINGDOM 25-27 (2016) (highlighting bipartisan support in the United States for state-level enterprise zones).

${ }^{7}$ Edward W. De Barbieri, Opportunism Zones, 39 Yale L. \& Pol’y ReV. 82, 136 (2020).

${ }^{8} I d$. at $88-89$.

${ }^{9}$ Id. at $144-46$.

Pitt Tax Review | ISSN 1932-1821 (print) 1932-1996 (online) DOI 10.5195/taxreview.2021.148 | http://taxreview.law.pitt.edu 
economic development tax incentives are designed, how they work, and what data is available to indicate successes or failures.

Let us discuss our data. First, we explore the Opportunity Zone. This author has argued elsewhere that Opportunity Zones have the possibility of benefitting opportunists-for instance, developers, investors, and professional advisors - to the exclusion of residents of the places designated for investment. ${ }^{10}$ The author arrives at this conclusion following a review of the structure and design of the Opportunity Zone law. ${ }^{11}$ In addition, viewed through the lens of use- and exchange-value, the author has critiqued Opportunity Zones to the extent that they fail to increase use-value to existing residents of particular places. ${ }^{12}$ Part II summarizes that argument. In addition, Part II discusses recent evidence that suggests that only a small portion of Opportunity Zones are even experiencing capital investment. Part II concludes that those who benefit from Opportunity Zones are few, and most likely investors who typically lack ties to the particular places designated for incentives. Of course, it is possible that the influx of capital will have additional benefits to those places. However, so far, the academic consensus is that Opportunity Zones are wasteful, their promises of growth specious, and their benefits illusory. ${ }^{13}$

${ }^{10} I d$. at 96-97, 130 (discussing aspects of the Opportunity Zone tool that favor investors and existing landowners at the expense of long-time residents who rent, as well as others).

${ }^{11} I d$. at $125-37$.

${ }^{12} I d$. at 143 . The concept of use-value has to do with the benefits other than selling and exiting property ownership. Id. at 127. Exchange-value is the value derived from transferring property to another owner in exchange for money, or something else of value. Id. Of course, properties with higher use-value may also enjoy a greater exchange-value as well. $I d$. at 128 . However, viewing use-value and exchangevalue independently offers a framework for conceiving how government interventions to direct private capital impact how owners and residents experience property and its benefits. Id. at 143, 148.

${ }^{13}$ Of the growing Opportunity Zone literature, no disinterested scholar has launched a full-throated defense of Opportunity Zones. For leading critiques of Opportunity Zones, see Michelle D. Layser, How Place-Based Tax Incentives Can Reduce Geographic Inequality, 74 TAX L. REV. 1 (2020) (exploring the failure of existing place-based tax incentives to reduce geographic inequality); Brandon Weiss, Opportunity Zones, 1031 Exchanges, and Universal Housing Vouchers, 110 CALIF. L. REV. (forthcoming 2022) (arguing that Opportunity Zones and the $\S 1031$ exchange should be scrapped and funds instead used for universal housing vouchers); Tracy A. Kaye, Ogden Commons Case Study: A Comparative Look at the Low-Income Housing Tax Credit and Opportunity Zone Tax Incentive Programs, 48 FORDHAM URB. L.J. 1067 (2021) (showing a worthwhile use of the Opportunity Zone tax incentive and arguing for improvements to the incentive). These studies stand in contrast to industry writings which are resoundingly upbeat and positive. See, e.g., IRA WEINSTEIN \& STEVE GLICKMAN, THE GUIDE TO MAKING

Pitt Tax Review | ISSN 1932-1821 (print) 1932-1996 (online)

DOI 10.5195/taxreview.2021.148 | http://taxreview.law.pitt.edu 
A broader theme that this Article draws out in Part II is the extent to which residents of low-income communities have an active part in the economic development of their neighborhoods. Unfortunately, the Opportunity Zone dramatically limits the agency of low-income people to effect change. One noted observer of the Opportunity Zone recently wrote that the "[Opportunity Zone] is just the latest example of policymakers and investors doing something to low-income communities rather than with them." 14

Limiting the participation of low-income people and communities is a flaw of the Opportunity Zone. ${ }^{15}$ Participation is but one aspect of ensuring that capital benefits communities in ways that are needed. Transparency is another key aspect. ${ }^{16}$ Unfortunately, the Opportunity Zone has limited transparency components, further impeding participation and local buy-in. ${ }^{17}$

Part III turns the focus to a state-based donation incentive that reduces taxpayers' state income taxes: the Massachusetts Community Investment Tax Credit. This state-level tax credit is introduced and existing data about outcomes are presented and discussed. ${ }^{18}$ There are elements of the

OPPORTUNITY ZONES Work: A RESOURCE FOR INVESTORS, DEVELOPERS, ENTREPRENEURS, AND COMMUNITY LEADERS (2020). The Brookings Institution convened a conference in February 2021 with an interdisciplinary group of academics presenting early findings on Opportunity Zone outcomes. Opportunity Zones: The Early Evidence, BROOKINGS INST. (Feb. 24, 2021), https://www.brookings.edu/ events/opportunity-zones-the-early-evidence/; see MATTHEW FrEEDMAN ET AL., BROOKINGS INST., THE IMPACTS OF OPPORTUNITY ZONES ON ZONE RESIDENTS (2021), https://www.brookings.edu/wp-content/ uploads/2021/01/Neumark-et-al.pdf (describing trends indicating existing residents are experiencing decreased unemployment, increased earnings, and reduced poverty of zone residents, following prior trends).

${ }^{14}$ Aaron Seybert, Mission, Money \& Markets: Is 2021 a Turning Point for the Opportunity Zones Incentive?, KRESGE FOUND. (June 10, 2021), https://kresge.org/news-views/mission-money-markets-is2021-a-turning-point-for-the-opportunity-zones-incentive/.

${ }^{15}$ See De Barbieri, supra note 7, at 93, 96.

${ }^{16} \mathrm{Id}$. at 93 .

${ }^{17} I d$. at 125 .

${ }^{18}$ Massachusetts has a history of early adoption of state-based laws. E.g., MASS. GEN. LAWS ANN. ch. 58 (West, Westlaw through ch. 55 of 2021 1st Annual Sess.) (colloquially known as "Romneycare" and often associated with the later federal "Obamacare" health insurance law); see also id. ch. 167, § 14 (in the area of community reinvestment and bank regulation, Massachusetts was an early adopter of statelevel bank regulation to ensure community-level capital access).

Pitt Tax Review | ISSN 1932-1821 (print) 1932-1996 (online)

DOI 10.5195/taxreview.2021.148 | http://taxreview.law.pitt.edu 
Massachusetts law that are unique, while other elements are similar to state laws in place elsewhere. ${ }^{19}$

The Massachusetts Community Investment Tax Credit is very different in scope, design, and features from the Opportunity Zone. First, it is a donation-based incentive that encourages individuals - who have at least one thousand dollars to contribute - to "invest," or more accurately, "donate," funds to a community development corporation to further the work of that organization. ${ }^{20}$ There are no returns in the form of private ownership distributions or earnings, since as a matter of law, no one "owns" a nonprofit organization. ${ }^{21}$ Second, community development corporations compete for a limited number of community investment tax credits. ${ }^{22}$ Third, donations received must be spent according to a community investment plan that allows both for tracking and accountability of funds used. ${ }^{23}$ Finally, donations are not tied to a strict geographic area - rather, they are tied to a particular lowand moderate-income community. ${ }^{24}$ By connecting funds to a particular community, and not a place alone, this economic development tool has elements of other people-based tools, such as Housing Choice Vouchers, the Earned Income Tax Credit, and benefits extended through the Supplemental Nutritional Assistance Program (often referred to by its acronym "SNAP").

\footnotetext{
${ }^{19}$ For a recent discussion about how states ought to respond to ineffective federal place-based investment tax incentives, see Michelle C. Perry, A State-Level Response to Ineffective Federal PlaceBased Investment Tax Incentives, 62 B.C. L. REV. 1969 (2021).

${ }^{20}$ MASs. GEN. LAws ANN. ch. 63, §38EE(e). Maryland funded ninety-seven projects during the 2020-2021 award years using a similar Community Investment Tax Credit. DHCD Dashboard, MD. DEP'T OF HOUS. \& CMTY. DEV., https://www.givemaryland.org/dashboard (last visited Dec. 1, 2021). Vermont has a similar incentive for the creation of affordable housing. VT. STAT. ANN. tit. 32, §5830c (West, Westlaw current through Acts 1 through 76 and M-1 through M-6, 2021-2022 Reg. Sess.). Fourteen states have laws that mirror the federal New Markets Tax Credit. State NMTC Programs, NOVOGRADAC, https://www.novoco.com/resource-centers/new-markets-tax-credits/state-nmtc-programs (last visited Dec. 1, 2021).

${ }^{21}$ For a study of the costs associated with removing tax exemption of nonprofit hospitals, see Jill R. Horwitz, Does Nonprofit Ownership Matter?, 24 YALE J. ON REG. 139, 157, 195 (2007) (exploring the social purposes and added services offered by nonprofit hospitals that lack shareholders and more limited offerings of for-profit hospital peers).

${ }^{22}$ Mass. Gen. Laws AnN. ch. 63, § 38E.

${ }^{23} \mathrm{Id}$. $38 \mathrm{EE}(\mathrm{b})(\mathrm{ix})$.

${ }^{24} I d . \S 38 \mathrm{EE}(\mathrm{b})$.
}

Pitt Tax Review | ISSN 1932-1821 (print) 1932-1996 (online) DOI 10.5195/taxreview.2021.148 | http://taxreview.law.pitt.edu 
There are potential benefits to what the author refers to as a communitybased tax incentive approach. ${ }^{25}$ A community-based approach follows the work of Michelle D. Layser in referring to community-oriented tax incentives - those that benefit existing residents. ${ }^{26}$ Principally, placing focus on a community instead of a place requires an articulation of the particular people who will benefit from the government subsidy. ${ }^{27}$ Also, since the mechanism of the intervention is a tax subsidy, lawmakers are able to direct capital to communities in need without having to directly issue grants, an indirect form of subsidy that avoids potential political opposition. But importantly, a competitive intervention to direct capital to community-based organizations has the potential to involve local residents in programs, services, and projects to meet resident needs, and not the needs of others, including outside investors. ${ }^{28}$

Part III evaluates the Massachusetts Community Investment Tax Credit in light of its design and stated goals. Part III then offers potential lessons learned for the Opportunity Zone from the community-based tax incentive

\footnotetext{
${ }^{25}$ In using the term "community-based" the author is indebted to the prior work of Michelle D. Layser in her conception of a "community-oriented" tax incentive. See Michelle D. Layser, A Typology of Place-Based Investment Tax Incentives, 25 WASH. \& LEE J. CIV. RTS. \& SOC. JUST. 403, 437 (2019) [hereinafter Layser, Typology] ("A tax incentive is community-oriented if it includes features that help ensure that residents will benefit from the investments."); Michelle D. Layser, The Pro-Gentrification Origins of Place-Based Investment Tax Incentives and a Path Toward Community Oriented Reform, 2019 WISC. L. REV. 745, 750 [hereinafter Layser, Pro-Gentrification Origins] ("[L]awmakers should introduce community oriented investment tax incentives that are specifically designed to benefit poor communities.").

${ }^{26}$ See Layser, Typology, supra note 25, at 437.

${ }^{27}$ In the case of the Massachusetts Community Investment Tax Credit, subsidized donations from taxpayers are provided to Community Development Corporations based on public policy ends that the Community Development Corporations articulate in their Community Investment Plans. Politically, some may be put off by a state government subsidizing certain nongovernmental organizations; however, the structure of the intervention as a tax credit may in fact make the tool more politically acceptable. For a discussion of the problems inherent in donations to nonprofit charities, see Eric Franklin Amarante, The Perils of Philanthrocapitalism, 78 MD. L. REV. 1 (2018) (cautioning against the use of for-profit vehicles in engaging in charitable activity because of the antidemocratic, paternalistic, and amateuristic aspects of philanthropy).

${ }^{28}$ Layser, Typology, supra note 25, at 437.
}

Pitt Tax Review | ISSN 1932-1821 (print) 1932-1996 (online)

DOI 10.5195/taxreview.2021.148 | http://taxreview.law.pitt.edu 
approach. ${ }^{29}$ Part IV draws out law and policy reforms that are uncovered in Parts II and III. Part V concludes this Article.

\section{WHOM DO OPPORTUNITY ZONES BENEFIT?}

The focus of this Part is on the Opportunity Zone tax incentive. After introducing what the Opportunity Zone incentive is, the Part turns to a discussion of whom the Opportunity Zone incentive benefits. Finally, this Part offers analysis in the form of a critique of the Opportunity Zone incentive.

\section{A. What Is It?}

The Investing in Opportunity Act was adopted by Congress and signed into law by the president as part of the 2017 Tax Cuts and Jobs Act. ${ }^{30}$ At its most basic level, investors who sell an asset and invest the profits from the sale in a Qualified Opportunity Fund are able either to defer or, in some cases, totally avoid capital gains tax, depending on how long the profits are invested. $^{31}$ The Opportunity Zone law was developed and lobbied for in Congress and the White House through a concerted, choregraphed, and coordinated approach. ${ }^{32}$

\section{B. Who Benefits?}

In his recent book Only the Rich Can Play, journalist David Wessel details the categories of individuals and groups benefiting from the Opportunity Zone incentive. ${ }^{33}$ Wessel highlights that wealthy people reduce

\footnotetext{
${ }^{29}$ For a more fulsome explanation of the importance of and need for a community-oriented tax incentive, see Layser, Pro Gentrification Origins, supra note 25, at 798-811.

${ }^{30}$ Tax Cuts and Jobs Act, Pub. L. No. 115-97, § 13823, 131 Stat. 2054, 2183 (2017) (codified at I.R.C. $\S 1400 Z-1$ to -2 ).

${ }^{31}$ See De Barbieri, supra note 7, at 121.

${ }^{32}$ A comprehensive, book-length treatment of the history of, and current outcomes related to, the Opportunity Zone incentive was recently published. DAVID WESSEL, ONLY THE RICH CAN PLAY: HOW WASHINGTON WORKS IN THE NEW GILDED AGE (2021).

${ }^{33}$ Id. at $12-21$.
}

Pitt Tax Review | ISSN 1932-1821 (print) 1932-1996 (online) DOI 10.5195/taxreview.2021.148 | http://taxreview.law.pitt.edu 


\section{8 |Pittsburgh Tax Review | Vol. 192021}

their tax liability through Opportunity Zone Fund investing, real estate developers attract capital through receipt of fund dollars, and the professionals stewarding the process-lawyers, accountants, consultantsbenefit as well. ${ }^{34}$ Those are the initial and most obvious beneficiaries of the Opportunity Zone incentive.

Professor Tracy Kaye has studied what she deems an appropriate use of Opportunity Zone funds in her article Ogden Commons Case Study: A Comparative Look at the Low-Income Housing Tax Credit and Opportunity Zone Incentive Tax Programs. ${ }^{35}$ As Kaye notes, her research points to greater regulation of the Opportunity Zone incentive through oversight including community-needs assessments and surveys. ${ }^{36}$ Further, the case study that Kaye investigates is "appropriate" largely due to project's use of the LowIncome Housing Tax Credit, which brings with it numerous additional oversight features. ${ }^{37}$

Additional scholars have explored whether, how, and if so, to what extent nonprofit organizations have harnessed the Opportunity Zone incentive to benefit communities. Michelle Layser, for instance, presents the differences between the Opportunity Zone incentive and its older cousin, the New Markets Tax Credit, particularly as they relate to nonprofit participation. ${ }^{38}$ As Layser points out, "unlike Opportunity Zones, the [New Markets Tax Credit] has often been used to support a variety of impactinvestment projects, including community facilities like YMCAs; nonprofit activities like soup kitchens, youth centers, and job training sites; and ... housing (always with an affordable component)." 39

Rashmi Dyal-Chand has proposed a change to the Opportunity Zone incentive to permit community banks to qualify as Opportunity Zone businesses and lend to business networks in Opportunity Zones, of which

${ }^{34} I d$. at 18 .

${ }^{35}$ See Kaye, supra note 13.

${ }^{36} I d$. at $1078-79$.

${ }^{37} \mathrm{Id}$. at 1088.

${ }^{38}$ Michelle D. Layser, Nonprofit Participation in Place-Based Tax Incentive Transactions, 48 FORDHAM URB. L.J. 1131, 1134 (2021).

${ }^{39} \mathrm{Id}$. at 1133.

Pitt Tax Review | ISSN 1932-1821 (print) 1932-1996 (online) DOI 10.5195/taxreview.2021.148 | http://taxreview.law.pitt.edu 
nonprofits are often a part. ${ }^{40}$ Anika Singh Lemar has suggested that placebased tax incentives such as Opportunity Zones be subject to local democratic decision-making processes, since the projects involve the development of public goods. ${ }^{41}$ Brandon M. Weiss has argued recently that clarifying the purchase rights of nonprofit developers of Low-Income Housing Tax Credit developments is a greater priority for Congress than fixing the failed Opportunity Zone incentive. ${ }^{42}$ Blaine G. Saito has argued that coordination among federal agencies might be one method for seeking community input on Opportunity Zone Fund investments. ${ }^{43}$

Each of the critiques mentioned above are aimed at improving outcomes for currently unrepresented stakeholders in the implementation of the Opportunity Zone incentive. Specifically, residents of Opportunity Zones are not able to voice a preference for how particular funds are invested and thus lack agency in deciding what projects might benefit them most. Members of Congress continue to keep a keen eye out for ways to extend Opportunity Zone incentives for investors. One recent bill introduced in the House of Representatives would expand the number of Opportunity Zones and extend the date by which investors can defer tax liability by three years. ${ }^{44}$

\section{A Critique of Opportunity Zones}

This author's central critique of the Opportunity Zone incentive is that when viewed through a use-transparency-participation framework, it fails to score high on any of the three critical lenses. ${ }^{45}$ With respect to use, it lacks

\footnotetext{
${ }^{40}$ Rashmi Dyal-Chand, Opportunity Zones, Collaborative Capitalism, and Community Banks: A Proposal, 48 FordHAM URB. L.J. 1227 (2021).

${ }^{41}$ Anika Singh Lemar, An Opportunity Zone Falls in a Forest, 48 FordHAM URB. L.J. 1183, 119899 (2021) ("You cannot design a program that can subsidize the production of what are, fundamentally, public goods that must be provided by the government.").

${ }^{42}$ Brandon M. Weiss, Clarifying Nonprofit Purchase Rights in Affordable Housing, 48 FORDHAM URB. L.J. 1159 (2021).

${ }^{43}$ Blaine G. Saito, Agency Coordination and Opportunity Zones, 48 FordHAm URB. L.J. 1203, 1223-24 (2021).

${ }^{44}$ Expanding Opportunity Zones Act of 2021, H.R. 4177, 117th Cong. (2021).

${ }^{45}$ See De Barbieri, supra note 7, at 93.
}

Pitt Tax Review | ISSN 1932-1821 (print) 1932-1996 (online) DOI 10.5195/taxreview.2021.148 | http://taxreview.law.pitt.edu 
focus on particular types of development, such as affordable housing. ${ }^{46}$ With respect to transparency, it lacks reporting requirements and metrics by which to measure success. ${ }^{47}$ Finally, with respect to participation, it lacks involvement of existing residents or intermediary organizations to offer input on needs for development projects. ${ }^{48}$

This issue of the Pittsburgh Tax Review adds to the growing Opportunity Zone literature. ${ }^{49}$ Scholarly viewpoints on the benefits of Opportunity Zones have tended towards the skeptical. ${ }^{50}$ Perspectives from industry, on the other hand, have been incredibly favorable. ${ }^{51}$ Recent research adds to the early analysis of Opportunity Zones.

One recent study by Patrick Kennedy and Harrison Wheeler shows how few of the designated Opportunity Zones are receiving investment dollars. The study of electronically filed tax returns shows that only sixteen percent of designated zones are receiving any investment. ${ }^{52}$ While the tax return data is not comprehensive, in that it is only electronically filed returns, it does point to important possible hypotheses. Namely, geographic inequality is a key dimension for law and policymakers to consider when enacting laws. ${ }^{53}$

The Kennedy and Wheeler study also points to a story about metropolitan regions, and the power of the nation's most productive

${ }^{46}$ Id. at $93-94$.

${ }^{47} I d$. at 96 .

${ }^{48}$ See id.

${ }^{49}$ See generally supra note 13.

${ }^{50}$ For instance, the Urban Institute published a report in 2020 observing nine occurrences related to the Opportunity Zone, with most indicating aspects in need of improvement. See BRETT THEODOS ET AL., URB. INST., AN EARLy ASSESSMENT OF OPPORTUNITY ZONES FOR EQUITABLE DEVElOPMENT PROJECTS 10, 14 (2020), https://www.urban.org/sites/default/files/publication/102348/early-assessmentof-ozs-for-equitable-development-projects_0.pdf.

${ }^{51}$ See, e.g., WeINSTEIN \& GLICKMAN, supra note 13, at 12-13.

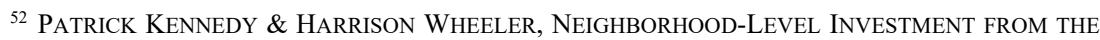
U.S. OPPORTUNITY ZONE PROGRAM: EARLY EVIDENCE 3 (2021), https://static1.squarespace.com/static/ 57a3c0fcd482e9189b09e101/t/607893b915858d7bd0d198ba/1618514881004/oz_kennedy_wheeler.pdf.

${ }^{53}$ See Ganesh Sitaraman et al., Regulation and the Geography of Inequality, 70 DUKE L.J. 1763, 1763-64 (2021).

Pitt Tax Review | ISSN 1932-1821 (print) 1932-1996 (online)

DOI 10.5195/taxreview.2021.148 | http://taxreview.law.pitt.edu 
geographic areas. ${ }^{54}$ The data Kennedy and Wheeler analyzed showed that the most populous commuting regions, including New York and Los Angeles, received the most Opportunity Zone investment. ${ }^{55}$ They conclude that "[t]racts receiving OZ investment are on average more densely populated and urban relative to other OZ tracts."

Perhaps one might conclude, based on this study, that Opportunity Zones benefit regions that are already experiencing capital investment. This finding is consistent with research about cities and the ability of subnational governments to influence industrial policy. ${ }^{57}$ To the extent that Opportunity Zones reinforce existing trends in economic development, it might not seem surprising that areas already attracting capital would continue to attract capital through the Opportunity Zone incentive.

Another recent study concludes that, from 2017 to 2019, apartment prices in designated Opportunity Zones saw significant price increases. ${ }^{58}$ The author of that study suggests that such a result demonstrates that the benefits of the Opportunity Zone were transferred to sellers of the apartments in the study. ${ }^{59}$ Thus, we have another beneficiary of the Opportunity Zoneresidential property owners.

\section{WHOM DOES THE MASSACHUSETTS COMMUNITY INVESTMENT TAX CREDIT BENEFIT?}

This Part introduces and discusses the Massachusetts Community Investment Tax Credit. After presenting the law and how it is designed to work as a tool for economic development, this Part explores the question: who benefits from the credit? If the credit is successful and fiscally prudent,

${ }^{54}$ KENNEDY \& WHEELER, supra note 52, at $15-16$.

${ }^{55} \mathrm{Id}$. at 15 .

${ }^{56} \mathrm{Id}$. at 18 .

${ }^{57}$ See, e.g., Richard C. Schragger, Federalism, Metropolitanism, and the Problem of States, 105 VA. L. REV. 1537, 1559 (2019).

${ }^{58}$ Edward F. Pierzak, Who Gains from Place-Based Tax Incentives? Exploring Apartment Sales Prices in Qualified Opportunity Zones, 47 J. PoRTFOlIO MgmT. ReAl Est. 145 (2021).

${ }^{59} \mathrm{Id}$.

Pitt Tax Review | ISSN 1932-1821 (print) 1932-1996 (online) DOI 10.5195/taxreview.2021.148 | http://taxreview.law.pitt.edu 
all states and even cities with income taxes ought to consider implementing it. However, if the tool is unproductive, it is perhaps a cautionary tale about a policy to avoid.

\section{A. What Is It?}

The Massachusetts Community Investment Tax Credit is a creature of state statute. ${ }^{60}$ The purpose of the tool is to "improve [the] economic opportunities for low and moderate income households" and individuals across geographic areas. ${ }^{61}$ Designation of a geographic area in which an investment can be made is a little complicated. An "economic target area" may be one designated by an Economic Assistance Community Council. ${ }^{62}$ This Council has authority to designate "targeted" areas based on high unemployment criteria, low income, poverty rate, heightened economic need, or potential for economic development. ${ }^{63}$

Low- and moderate-income communities include "enhanced economic enterprise communit[ies] or empowerment zone[s]." ${ }^{34}$ Further, the law allows a city or town to designate a low- and moderate-income community based on income levels and unemployment rate. ${ }^{65}$

In addition to a designated geographic area, and particular population, the tool includes a selection mechanism for community development corporations. ${ }^{66}$ Approximately a third of the community development Sess.).

${ }^{60}$ MASS. GEN. LAWS ANN. ch. 63, § 38EE (West, Westlaw through ch. 55 of 2021 1st Annual

${ }^{61} I d . \S 38 \mathrm{EE}(\mathrm{a})$.

${ }^{62} I d . \S 38 \mathrm{EE}(\mathrm{b}) ;$ id. ch. $23 \mathrm{~A}, \S 3 \mathrm{G}$.

${ }^{63} \mathrm{Id}$. ch. $23 \mathrm{~A}, \S 3 \mathrm{G}(\mathrm{b})$. With respect to economic need, the statute is very specific: it talks about industrial or military base closure, underutilized maritime or electric generation facility, or areas with "commercial vacancy rate greater than 20 per cent." Id. With respect to areas with exceptional potential for economic development, there is also a great deal of specificity. Id. The definition includes "blighted" areas with abandoned buildings larger than a million square feet, regional technology centers, and renewable energy generation facilities. Id.

${ }^{64} \mathrm{Id}$. ch. $63, \S 38 \mathrm{EE}(\mathrm{b})$. Empowerment Zones are federal place-based tools to spark economic activity, currently inactive. I.R.C. § 1397B(c).

${ }^{65}$ Mass. Gen. Laws AnN. ch. 63, § 38EE(b).

${ }^{66} \mathrm{Id}$.

Pitt Tax Review | ISSN 1932-1821 (print) 1932-1996 (online)

DOI 10.5195/taxreview.2021.148 | http://taxreview.law.pitt.edu 
corporations selected must serve gateway municipalities. ${ }^{67}$ A fifth of the community development corporations must serve rural areas. ${ }^{68}$

To apply for and receive a credit allocation, a certified community development corporation must develop a community investment plan ${ }^{69}$ The community investment plan must include elements describing the community to be served, the level of engagement of community residents, description of collaborative efforts to support implementation, and how the "plan fits into [the] larger strategy" of the community. ${ }^{70}$ The plan also must include the goals to be achieved during the time period of the plan, including "how low- and moderate-income households or low- and moderate-income communities will benefit and how the entire community will benefit.",71 There are not specific measures stated in the statute regarding how the goals will be measured, but the plan must include "the manner in which success shall be measured and evaluated."72

If the community partner has not fully utilized their tax credit allocation within three years, they may apply for a one-year extension. ${ }^{73}$ The tax credit might be revoked if:

(i) the community partner has been unable to secure donation commitments for at least 50 per cent of total allocation by that time, (ii) if the community partner is found to be in noncompliance with this statute or the department's regulations promulgated hereunder, [(iii)] if the community partner is determined by the department to be making inadequate progress on its community investment plan, or (iv) for other good cause as determined by the department. ${ }^{74}$

${ }^{67} I d$. $\S 38 \mathrm{EE}(\mathrm{c})(2) ; i d$. ch. $23 \mathrm{~A}, \S 3 \mathrm{~A}$ (defining a “' gateway municipality' [as] a municipality with a population greater than 35,000 and less than 250,000 with a median household income below the commonwealth's average and a rate of educational attainment of a bachelor's degree or above that is below the commonwealth's average").

${ }^{68} \mathrm{Id}$. ch. $63, \S 38 \mathrm{EE}(\mathrm{c})(2)$.

${ }^{69} \mathrm{Id}$. $\S 38 \mathrm{EE}(\mathrm{b})$.

${ }^{70} I d$. $338 \mathrm{EE}(\mathrm{b})(\mathrm{i})-(\mathrm{ii})$, (vii).

${ }^{71} I d$. $\S 38 \mathrm{EE}(\mathrm{b})(\mathrm{iii})$.

${ }^{72} I d . \S 38 \mathrm{EE}(\mathrm{b})(\mathrm{v})$.

${ }^{73} \mathrm{Id} . \S 38 \mathrm{EE}(\mathrm{c})(3)$.

${ }^{74} \mathrm{Id}$.

Pitt Tax Review | ISSN 1932-1821 (print) 1932-1996 (online) DOI 10.5195/taxreview.2021.148 | http://taxreview.law.pitt.edu 
There is a requirement that community partners and community partnership funds provide annual reports regarding outcomes achieved during the prior year. ${ }^{75}$ These annual reports should be available to the public. The department should also produce an annual report no later than April 30 each year for the public and the state legislature that describes the outcomes achieved through the Massachusetts Community Investment Tax Credit Program. ${ }^{76}$

\section{B. Who Benefits?}

The Massachusetts tax incentive is marketed to a much more modest investor than is the Opportunity Zone. In one piece of marketing material, proponents of the incentive describe how to create $\$ 10,000$ of investment from a $\$ 1,500$ cash donation. ${ }^{77}$ A modest $\$ 1,500$ contribution yielding a $\$ 10,000$ capital investment is much smaller than the $\$ 100,000$ most investors must contribute to take advantage of the incentives offered by Opportunity Zones. Nevertheless, investors are one set of constituents who benefit from the Massachusetts tax incentive.

Another clear group of beneficiaries is community development corporations. These nonprofit organizations are regularly asked to report about how the tax incentive has improved their programs. ${ }^{78}$ Key areas of benefit include internal capacity, increased activities, engagement with communities to be served, and increases in funding. ${ }^{79}$ In particular, available data shows how each funded organization is engaging local stakeholders through their respective Community Investment Plans. ${ }^{80}$ Community

${ }^{75} I d . \S 38 \mathrm{EE}(\mathrm{c})(8)$.

${ }^{76} \mathrm{Id}$.

77 Community Investment Tax Credit Program, Hous. CoRp. OF ARLington, https://www. housingcorparlington.org/support-us/citc-program/ (last visited Oct. 26, 2021).

${ }^{78}$ MASS. GEN. LAWS ANN. ch. 63, § 38EE(c)(8).

${ }^{79}$ Mass. Ass'N of CMty. Dev. Corps., Community Investment TaX Credit: Program IMPACT 1 (2019), https://app.powerbi.com/view?r=eyJrIjoiNjI3MTk1ZGMtN2U4ZC00MjE2LThmZTY tMDQ2NjkzODhmMjI5IiwidCI6ImU5YmNiN2M3LTYzN2ItNGYwOC04Nzc4LTU3NjFmMTUxM2 Y4OSIsImMiOjN9.

${ }^{80} I d$. at 4.

Pitt Tax Review | ISSN 1932-1821 (print) 1932-1996 (online) DOI 10.5195/taxreview.2021.148 | http://taxreview.law.pitt.edu 
Investment Plans are available on the Massachusetts Department of Housing and Community Development website. ${ }^{81}$

One organization that is well-documented in the literature is Dudley Neighbors Inc. (Dudley Neighbors). Dudley Neighbors is a community land trust based in Boston's Roxbury and North Dorchester neighborhoods that was formed in $1984 .{ }^{82}$ The efforts to organize the residents in these multiracial, multiethnic neighborhoods was documented in the $1990 \mathrm{~s} .{ }^{83}$ The Community Investment Plan for Dudley Neighbors for 2014-2016 outlines in great detail the community to be served, the involvement of community residents and stakeholders in developing the plan, plan goals, the activities to be undertaken, the methods of evaluation, the efforts to achieve collaboration, integration with existing activities, financing strategy, and history of success. ${ }^{84}$ This Community Investment Plan is comprehensive, detailed, and similar to the standards of reporting generally required by foundation and other charitable donors. The goals are evaluated with specific outcomes. Ensuring outcomes are reached is part of the process since continued funding is contingent on reapplication.

\section{Tracking How Community Development Corporations Spent Funds}

Massachusetts Community Investment Tax Credit funds are reported through a survey updated annually by the Massachusetts Association of Community Development Corporations. ${ }^{85}$ Metrics are reported across four areas with respect to the community development corporations that use funds

${ }^{81}$ Community Investment Tax Credit Program, MASS. DeP'T OF Hous. \& CMTY. DEV., https://www .mass.gov/service-details/community-investment-tax-credit-program-citc (last visited Dec. 1, 2021).

${ }^{82}$ Emily Thaden \& Jeffrey S. Lowe, Resident and Engagement in Community Land Trusts 8 (Lincoln Inst. of Land Pol'y, Working Paper No. WP14ET1, 2014).

${ }^{83}$ Peter Medoff \& Holly Sklar, Streets of Hope: The Fall and Rise of an Urban NEIGHBORHOOD (1994).

${ }^{84}$ Dudley NeIghbors InC., Community InVESTMent Plan 2014-2016, https://www.macdc .org/sites/default/files/user14/Dudley\%20Neighbors\%20Inc.pdf (last visited Dec. 1, 2021).

${ }^{85}$ MASS. Ass'N OF CMTY. DEv. CORPS., COMMUnity InVESTMENT TAX CREDIT: INTRODUCTION 1 (2019), https://app.powerbi.com/view?r=eyJrIjoiNzIyOTEyNzUtMDdmZi00MmMxLThlOTktZDN hY2VkYmZhZDAwIiwidCI6ImU5YmNiN2M3LTYzN2ItNGYwOC04Nzc4LTU3NjFmMTUxM2Y4O SIsImMiOjN9.

Pitt Tax Review | ISSN 1932-1821 (print) 1932-1996 (online) DOI 10.5195/taxreview.2021.148 | http://taxreview.law.pitt.edu 
donated through the credit. ${ }^{86}$ Those areas are: internal capacity, activities, engagement, and funding. ${ }^{87}$

With respect to internal capacity, the greatest area of increased internal capacity came from increases to space or equipment. ${ }^{88}$ Other types of increased capacity include staffing, information, and communication systems. ${ }^{89}$ With respect to activities, a number of activities increased, including real estate development, community organizing, housing services, arts and culture events, and financial stability services. ${ }^{90}$ With respect to engagement, increases were measured across increased attendance at events, increased volunteerism, and new resident engagement structures. ${ }^{91}$ Finally, with respect to funding, most community development corporations reported an expectation that funds would increase over time given the additional funds donated through the Massachusetts Community Investment Tax Credit. ${ }^{92}$

\section{Similarities and Differences with Opportunity Zones}

As a practical matter, the Opportunity Zone and the Massachusetts Community Investment Tax are very different. The Massachusetts credit is a donation tax credit which differs from a true investment credit where an investor seeks a financial gain. ${ }^{93}$ In that way, the Massachusetts incentive is more akin to the deduction taxpayers are able to take for donations to organizations with recognition of tax exemption under $\S 501(\mathrm{c})(3)$ of the Internal Revenue Code. ${ }^{94}$

Nevertheless, while the "investment" in the Massachusetts incentive may more accurately be characterized as a donation, there is a subsidy

\footnotetext{
${ }^{86}$ MASS. Ass'N OF CMTY. Dev. CoRPS, supra note 79, at 1.

${ }^{87} \mathrm{Id}$.

${ }^{88} I d$. at 2.

${ }^{89} \mathrm{Id}$.

${ }^{90} I d$. at 3.

${ }^{91}$ Id. at 4 .

${ }^{92}$ Id. at 5 .

${ }^{93}$ E-mail from Joe Kriesberg, President, Mass. Ass'n of Cmty. Dev. Corps. to Edward De Barbieri (June 7, 2021) (on file with author).

${ }^{94}$ I.R.C. $\S 170$.
}

Pitt Tax Review | ISSN 1932-1821 (print) 1932-1996 (online) DOI 10.5195/taxreview.2021.148 | http://taxreview.law.pitt.edu 
involved. The subsidy is supposed to direct capital to particular communities - in this case, low- and moderate-income ones. Plus, there is an intermediary organization involved - the charitable nonprofit receiving the capital to expand its programs.

The Massachusetts incentive offers a state income tax subsidy to direct cash to nonprofit groups. Skeptically viewed, some might question the wisdom or need for such a subsidy - in other words, why extend a government tax incentive for donating funds to a nongovernmental entity? Some might argue that such funds would be better spent on government programs, or by reducing resident tax obligations.

In addition, viewed through a use-transparency-participation framework, the Opportunity Zone and the Massachusetts Community Investment Tax Credit are very different. The level of detail required to participate in the Massachusetts tax credit is much higher. With respect to use, in the Massachusetts example, funds go to certified community development corporations. ${ }^{95}$ For the Opportunity Zone, funds are flowing mostly to market-rate commercial real estate. ${ }^{96}$

With respect to transparency, there are also significant differences. To even apply for credits, a certified community development corporation must have a community investment plan explaining how funds will be spent, and how low- and moderate-income communities will benefit. ${ }^{97}$ Opportunity Zones, on the other hand, allow investors to claim the tax incentive essentially as of right. ${ }^{98}$

Finally, with respect to participation, the two tools are also very different. Community development corporations in Massachusetts must describe in their community investment plans how residents will participate

\footnotetext{
${ }^{95}$ Mass. Gen. Laws ANN. ch. 63, §38EE(b) (West, Westlaw through ch. 55 of 2021 1st Annual Sess.).

${ }^{96}$ De Barbieri, supra note 7, at 82, 136.

${ }^{97}$ Mass. GEN. Laws ANN. ch. 63, § 38EE(b)(iii), (ix).

${ }^{98}$ De Barbieri, supra note 7, at 82, 136.
}

Pitt Tax Review | ISSN 1932-1821 (print) 1932-1996 (online) DOI 10.5195/taxreview.2021.148 | http://taxreview.law.pitt.edu 
in the plan. ${ }^{99}$ Such participation is not required at all in Opportunity Zone investments. ${ }^{100}$

The two tools also appear to have raised significantly different amounts of capital. The Massachusetts tool has raised $\$ 49$ million since 2012. ${ }^{101}$ At least one database of self-reported Opportunity Zone funds estimates that capital invested in Massachusetts Opportunity Zones is approximately $\$ 1.135$ billion, and the Opportunity Zone incentive was adopted into law in $2017 .^{102}$

\section{HOW SHOULD THE "WHO BENEFITS?" QUESTION INFLUENCE LAW AND POLICY REFORM OF PLACE-BASED ECONOMIC DEVELOPMENT STRATEGIES?}

To the extent that a community-based tool such as the Massachusetts Community Investment Tax Credit is successful, elements of the tool might be useful for reforming the federal Opportunity Zone incentive. The emphasis on funding community development corporations is an interesting one to test, especially in light of the research that Kaye, Layser, and others have engaged in with respect to Opportunity Zones. Specifically, would Opportunity Zone projects become more effective with the inclusion of a nonprofit community development corporation?

For Kaye, in her Ogden Commons case study, it is the additional use of the Low-Income Housing Tax Credit and the presence of a nonprofit organization that drove community engagement leading to an appropriate use of Opportunity Zone Fund capital. ${ }^{103}$ The total lack of a mission-driven focus leads the Opportunity Zone incentive off course. Admittedly, for Kaye, "[s]ocial impact projects like Ogden Commons require many layers of

${ }^{99}$ MAss. Gen. LAws ANN. ch. 63, § 38EE(b)(ii).

${ }^{100}$ De Barbieri, supra note 7, at 96.

${ }^{101}$ Community Investment Tax Credit Program, supra note 77.

${ }^{102}$ List of Massachusetts Opportunity Zone \& OZ Funds, OPPORTUNITY ZONES DATABASE, https:// opportunitydb.com/location/massachusetts/ (last visited Oct. 26, 2021).

${ }^{103}$ Kaye, supra note 13, at 1105 ("This Ogden Commons case study has demonstrated the benefit of community engagement that came about because of the involvement of a nonprofit organization and other mission-driven investors.").

Pitt Tax Review | ISSN 1932-1821 (print) 1932-1996 (online) DOI 10.5195/taxreview.2021.148 | http://taxreview.law.pitt.edu 
subsidy." 104 Stacking various incentives makes such mixed-use development projects possible in locations that would not otherwise attract such investment.

For Layser, numerous barriers exist for nonprofit participation in the Opportunity Zone context. ${ }^{105}$ This has to do with what Layser points out as the requirements that Opportunity Zone Fund investments must take the form of equity as well as the structure of the incentive as a capital gains deferral. ${ }^{106}$ Structuring the investment as equity instead of debt excludes nonprofits that cannot on their own raise equity through selling shares. ${ }^{107}$ Layser further notes that nonprofits are unable to raise funds through the Opportunity Zone incentive because it does not offer a tax credit that can be sold. ${ }^{108}$ Layser's final point is that many entities, including nonprofits, are unlikely to participate in Opportunity Zone deals because the status of such deals with respect to Community Reinvestment Act eligibility is uncertain. ${ }^{109}$

Turning back to the Massachusetts Community Investment Tax Credit, the argument for the presence of a community development corporation in improving the allocation of capital to serve the community may be stronger. Mission-based organizations have the possibility of improving outcomes for real estate projects in low-income areas. Lowering barriers to nonprofit participation, offering a favorable structure for nonprofits to invest, and designing a strategy to direct capital to nonprofits offers a way for nonprofits to be partners in place-based economic development strategies.

There are other aspects of the Massachusetts Community Investment Tax Credit that could be used to improve the Opportunity Zone incentive. As

\footnotetext{
${ }^{104} \mathrm{Id}$.

${ }^{105}$ Layser, supra note 13, at 1134.

${ }^{106}$ Id. at $1149-53$.

${ }^{107} I d$. at 1150 . Layser adds that Opportunity Zone Funds cannot satisfy their asset-holding obligations through funding nonprofits since investments must be made as equity, and not debt. Id.

${ }^{108} I d$. at $1150-51$.

${ }^{109} I d$. at 1151-52. In each case, Layser argues, the New Markets Tax Credit invites nonprofit participation through allowing debt involvement, creating a mechanism for nonprofits to raise funds through tax credit sale, and providing certainty regarding Community Reinvestment Act eligibility. Id. at
} $1149-53$.

Pitt Tax Review | ISSN 1932-1821 (print) 1932-1996 (online) DOI 10.5195/taxreview.2021.148 | http://taxreview.law.pitt.edu 


\section{0 |Pittsburgh Tax Review | Vol. 192021}

the Opportunity Zone incentive currently stands, capital invested in Opportunity Zone Funds is not limited. Without limiting capital investment, there is no competition and thus no need for each project to justify the need for the public subsidy. An element of competition would require each project to justify its subsidy. ${ }^{110}$ In addition, a competition would afford an additional layer of protection to ensure that funds are well spent. ${ }^{111}$

\section{CONCLUSION}

Answering the question "who benefits" from place-based economic development tax incentives is not a straightforward endeavor. To the extent that the Opportunity Zone, the most recent form of federal place-based economic development tool, needs to be improved, it may benefit from particular features - such as an emphasis on community investment - that are associated with the Massachusetts Community Investment Tax Credit. Policy design features that focus on delivering capital to nonprofits, requiring community engagement planning, and assessing outcomes based on community-oriented goals are all likely to improve quality of life for residents in low-income communities. As Congress and the Biden administration consider proposals to modify the Opportunity Zone incentive, looking to successful state-level incentives may prove fruitful.

${ }^{110}$ Kriesberg, supra note 93.

${ }^{111} I d$.

Pitt Tax Review | ISSN 1932-1821 (print) 1932-1996 (online) DOI 10.5195/taxreview.2021.148 | http://taxreview.law.pitt.edu 
APPENDIX A-LOCATIONS OF MASSACHUSETTS COMMUNITY INVESTMENT TAX CREDIT DONORS

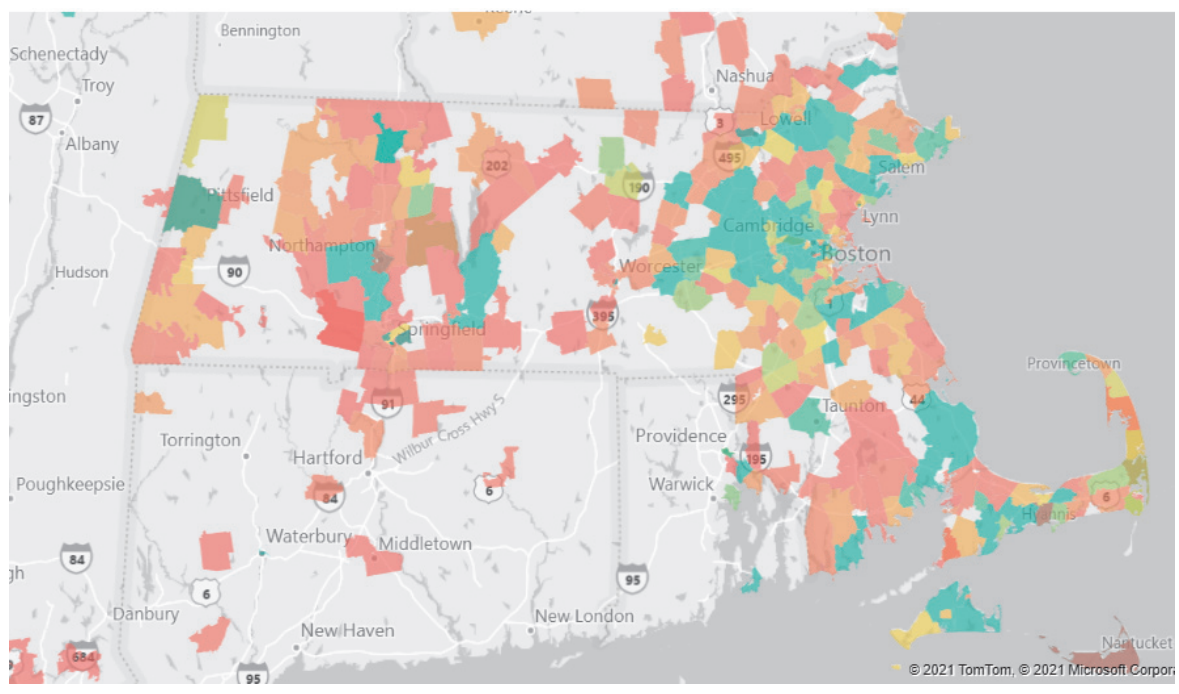

Source: Massachusetts Association of Community Development Corporations, Community Investment Tax Credit, https://app.powerbi.com/view?r=eyJrljoiMGUxYzg4NzItZGZhNi00OTA2 LWFmNDItNDA1NTM0YzQxZmMzIiwidCI6ImU5YmNiN2M3LTYzN2I tNGYwOC04Nzc4LTU3NjFmMTUxM2Y4OSIsImMiOjN9. 


\section{2 |Pittsburgh Tax Review | Vol. 192021}

APPENDIX B-DESIGNATED OPPORTUNITY ZONES IN MASSACHUSETTS

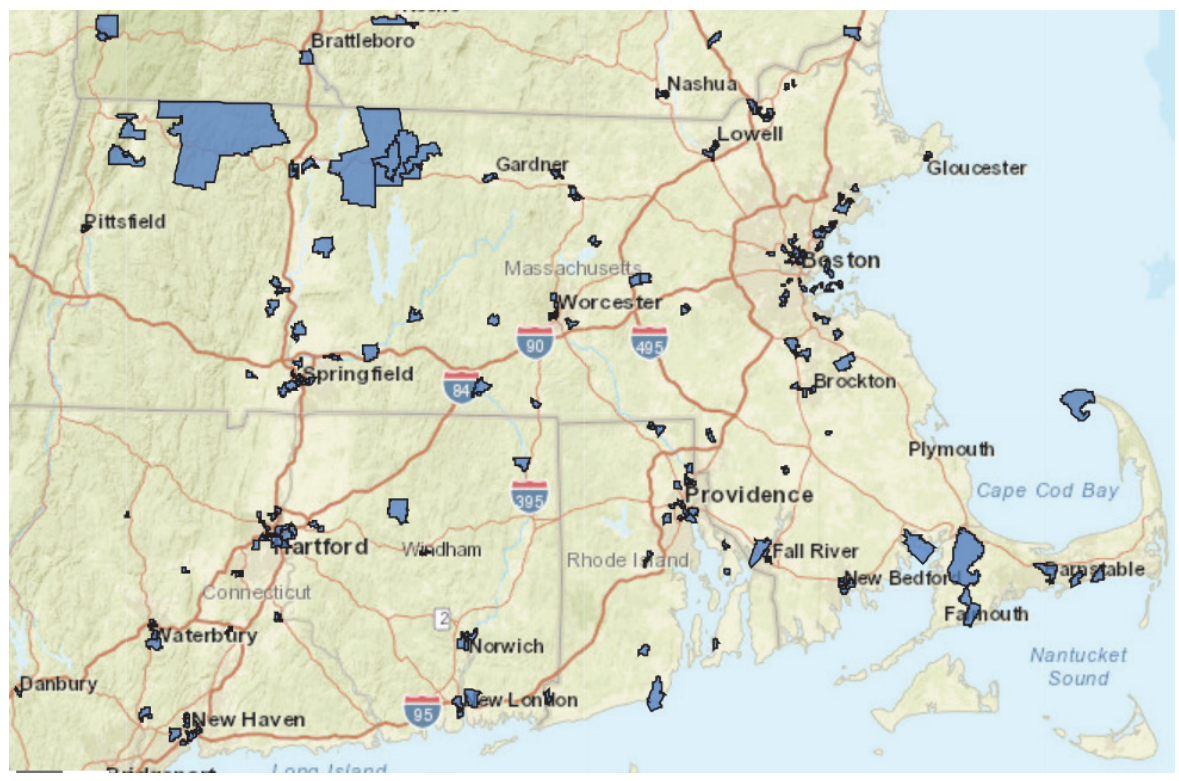

Source: Opportunity Zones Database, List of Massachusetts Opportunity Zones \& OZ Funds, https://opportunitydb.com/location/massachusetts/.

Pitt Tax Review | ISSN 1932-1821 (print) 1932-1996 (online) DOI 10.5195/taxreview.2021.148 | http://taxreview.law.pitt.edu 